\title{
Hubungan agenda media dan faktor keselarian politik
}

\author{
Noor Zafira Mohd Shafie, Haryati Abdul Karim \& Norhuda Salleh \\ Universiti Malaysia Sabah
}

\begin{abstract}
Abstrak
Artikel ini memfokuskan pada penggunaan Teori Penentuan Agenda dan Pilihan Raya Kecil Parlimen Rompin dan Permatang Pauh 2015. Objektif kajian ini adalah untuk mengenalpasti penentuan agenda media antara akhbar Utusan Malaysia dan portal berita Free Malaysia Today, dan menganalisis corak liputan berita yang dibuat oleh kedua-dua media yang berlainan pemilikan dengan meneliti aspek tema berita dan condong berita. Kajian yang dijalankan ini menggunakan kaedah analisis kandungan kuantitatif. Tema berita yang dikenal pasti adalah sosial, ekonomi dan tokoh. Tema ini dipecahkan kepada sub tema yang lebih kecil. Tema sosial dipecahkan kepada jenayah, pendidikan dan kaum dan agama, ekonomi dipecahkan kepada pembangunan dan GST dan tema tokoh pula dipecahkan kepada sub tema calon bertanding, manifesto dan kempen dan sistem pilihan raya. Condong berita yang dikenal pasti dalam kajian adalah positif kerajaan, positif pembangkang, neutral, negatif kerajaan dan negatif pembangkang. Kajian mendapati bahawa proses penentuan agenda berlaku bagi setiap liputan media yang dipaparkan kerana terdapat kecenderungan tertentu bagi jenis liputan berita yang dibuat oleh media berdasarkan kepada penekanan tema dan sub tema tertentu dan hal ini turut dilihat berdasarkan kepada condong berita. Faktor keselarian politik dikaitkan dengan penentuan agenda media kerana pemaparan skop berita yang berdasarkan kepada tema dan arah kecenderungan berita adalah berpandukan kepada faktor pemilikan media kerana kedua-dua media adalah berbeza pemilikan. Utusan Malaysia dimiliki oleh UMNO manakala Free Malaysia Today dimiliki oleh pembangkang. Kesimpulannya kajian ini mengukuhkan Teori Penentuan Agenda khususnya tentang hubungan agenda media dengan keselarian politik.
\end{abstract}

Kata Kunci: Kecenderungan, Agenda, Tema, Keselarian, Politik

\section{Pengenalan}

Menurut Kim, Han, Choi, \& Kim (2012) media mungkin berguna dan berupaya untuk memberi kesan pantas dan segera kepada pendapat khalayak. Hal tersebut dijelaskan setelah beliau merujuk kepada Teori Penentuan Agenda yang dikemukakan oleh (McCombs \& Shaw (1972) yang mengatakan bahawa media mempunyai kekuatan untuk membuatkan sebuah isu diterima dan dianggap penting dengan menonjolkan isu tersebut secara kerap dalam liputan berita. Kunci dasar kepada Teori Penentuan Agenda ialah media dapat meyakinkan dalam melahirkan fokus tumpuan isu yang tertentu dan menyusun kepentingan isu mengikut hierarki.

Liputan berita yang dibuat oleh agensi berita mempunyai kecenderungan tertentu seperti positif, negatif ataupun neutral. Hal ini adalah bertujuan bagi menonjolkan sesuatu imej yang tertentu. Bahtiar Mohamad, Hassan Abu Bakar, \& Mohamad Khadafi Hj Rofie (2004) komunikasi massa merupakan satu proses yang mana sebuah organisasi media menyalurkan maklumat atau mesej kepada khalayak ramai dan mesej itu boleh mempengaruhi khalayak. Oleh yang demikian, media sememangnya berperanan dalam menonjolkan sesuatu imej yang tertentu. Agenda media ialah tahap pertama bagi fasa Teori Penentuan Agenda. Dalam tahap pertama, fungsi Teori Penentuan Agenda adalah tertumpu kepada pengawal media yang dikenali sebagai tapisan (gatekeeper). Media yang berlainan mempunyai agenda media yang berlainan. Fasa awal perkembangan Teori Penentuan Agenda, Shaw (1979) menjelaskan bahawa penetapan agenda mempunyai hubungan antara perseorangan dalam 
menentukan kesan muktamad kandungan media kepada khalayak. Hal ini kerana, agenda media yang ditetapkan oleh media akan diterima oleh khalayak dan difikirkan sebagai satu yang penting. Keselarian politik dengan media dilihat sebagai suatu faktor yang mencorakkan sistem komunikasi dan maklumat bagi sesebuah negara.

Kajian perbandingan sistem media yang dijalankan oleh sarjana lampau menjelaskan keselarian politik (political parallelism) sebagai satu kajian yang menganalisis ciri-ciri dan perkaitan antara ahli politik dan kecondongan politik media dalam pelaporan beritanya. Penciptaan gabungan media di antara parti politik yang dominan (arus perdana) sama ada secara jelas atau tersirat akan mewujudkan persaingan dalam politik. Fasa awal kemunculan kajian perbandingan sistem media yang meneliti kepada keselarian politik telah dijalankan oleh Hallin dan Mancini yang mana dalam penulisan mereka tentang perbandingan sistem media, media dianalisis mengikut empat dimensi iaitu pembangunan media, keselarian politik, profesionalisme dalam kewartawanan dan campur tangan kerajaan (gatekeeper). Konsep keselarian politik menegaskan bahawa konsep tersebut merupakan satu penelitian yang merujuk kepada kandungan media dan sejauh mana media yang berbeza pemilikan mencerminkan orientasi politik yang berbeza khususnya dalam liputan berita yang disiarkan. Keselarian politik dalam media boleh dilihat melalui sesebuah institusi media itu sendiri yang mana terdapat pelbagai media dengan pelbagai kecenderungan ideologi yang berbeza. Media dan politik berhubungan dan faktor keselarian politik terjadi kerana terdapat pelbagai media yang berlainan ideologi seperti pro-kerajaan, pro-pembangkang dan neutral (Hallin \& Paolo, 2004). Idea ini turut menyokong apa yang telah dijelaskan oleh Swanson (1997) iaitu memahami sifat komunikasi politik dalam pilihan raya juga boleh menyumbang kepada memperkayakan pengetahuan tentang hubungan yang sentiasa berubah-ubah di antara media dan politik.

Media cetak dan media elektronik boleh dikategorikan sebagai media yang bebas, mempunyai kecenderungan tertentu atau neutral dalam menyampaikan maklumat berkenaan politik kepada khalayak bagi tujuan demokrasi dan keputusan. Pada awal abad ke-18 hingga awal abad ke-19, media cetak iaitu akhbar mula menunjukkan wujudnya darjah kecenderungan dalam liputan berita yang disiarkan. Karl W. Deutsch berpendapat bahawa semua sistem politik memerlukan rangkaian atau jaringan komunikasi dan beliau menjelaskan bahawa sesuatu sistem politik hanya akan berjaya mengatasi sebarang masalah sistem jika mempunyai hubungan komunikasi antara komponen sistem (Ramanathan, 2003). Menurut Artero (2014), faktor pemilikan media yang melibatkan parti politik bermula pada pertengahan fasa kedua abad ke-19. Parti politik di Eropah khususnya pada masa itu mula menggunakan media bagi tujuan pelancaran parti baru, atau meraih sokongan khalayak berkenaan sesuatu pendapat. Persaingan politik adalah selari dengan persaingan media. Rakyat atau khalayak boleh mengakses pertambahan sumber maklumat daripada pelbagai sumber akhbar, saluran media elektronik dan laman sesawang. Kandungan berita yang dipaparkan oleh media adalah cenderung kepada kedudukan parti tertentu. Ramanathan (2003) menjelaskan bahawa mulai abad ke-14, negara benua Eropah telah mula memperluaskan kawasan naungan dengan menakluki kawasan di benua Asia, Afrika dan Amerika Syarikat. Tahap itulah telah menjadi tahap permulaan ilmu baharu seperti percetakan dan semangat penerokaan dalam semua bidang manusia. Hal itu telah membawa kepada perkembangan tamadun dan mencetuskan peperangan serta teknologi yang diguna pakai dalam peperangan sekali gus membawa kepada penubuhan organisasi antarabangsa yang disertai oleh semua negara di dunia. Selaras dengan perkembangan yang berlaku dalam bidang politik, proses pembentukan keputusan dan maklumat mula berlaku kerana satu persaingan untuk 
menentukan 'siapa mendapat apa, bila dan bagaimana'. Hal ini membuktikan bahawa sistem politik mula memainkan peranan sebagai penentu kepada banyak perihal.

Hong Kong merupakan satu contoh penelitian keselarian politik yang dilihat oleh sarjana dalam bidang komunikasi. Dengan populasi penduduk lebih tujuh juta dan persekitaran media yang mewah meliputi 50 buah akhbar, dua siaran televisyen percuma dan beberapa siaran televisyen berbayar, menjadikan Hong Kong tidak jauh berbeza daripada segi pandangan masyarakatnya. Menurut Chan \& Lee (2014), dalam sistem politik Hong Kong, terdapat dua kecenderungan iaitu pihak pro-demokrasi yang mendapatkan hak mengundi bebas dalam pilihan raya bagi ketua eksekutif dan badan perundangan, manakala pihak prokerajaan lebih suka untuk mendemokrasikan pada kadar yang tidak membangkitkan kemarahan kerajaan China, yang mengambil alih kedaulatan Hong Kong pada tahun 1997. Ideologi ini membuktikan bahawa Hong Kong adalah sebuah kerajaan yang mencerminkan wujudnya keselarian politik dengan media. Hal ini kerana pemerintahan kerajaan yang berbeza kecenderungan yang melibatkan pro-demokrasi, pro-kerajaan dan media bebas. Peranan media sebagaimana yang dijelaskan oleh Syed Arabi Idid (1994) sebagai pembentuk agenda sangat penting kerana maklumat yang disampaikan media adalah diterima oleh khalayak khususnya bagi tempoh masa pilihan raya berlangsung.

Dalam kajian yang meneliti agenda politik media, peranan institusi media sebagai pemberi maklumat diukur melalui isu yang diketengahkan dalam pelaporan berita (Walgrave \& Aeist, 2006) Agenda media merupakan satu pecahan dari Teori Penentuan Agenda. Dalam kata lain Kiong (1991) menjelaskan terdapat dua pihak yang berperanan sebagai pembentuk agenda setiap berita iaitu parti yang dikenal pasti sebagai pihak yang menentukan agenda media dan pihak yang menyuarakan media dengan lebih kuat. Hal inilah yang diteliti dalam kajian terhadap Utusan Malaysia dan Free Malaysia Today yang dijalankan dengan tujuan meneliti agenda media yang dibawa oleh media yang berlainan pemilikan dan kaitan pelaporan berita dengan faktor keselarian politik dengan menggunakan tema berita dan condong berita. Beliau turut menjelaskan bahawa agenda media telah mengemukakan beberapa pemboleh ubah yang boleh dilihat dalam kajian iaitu hak milik atau kemiripan agensi media. Persoalan tentang 'siapa yang menetapkan agenda media' adalah telah dibangkitkan oleh sarjana lampau sejak awal kajian tentang Teori Penentuan Agenda dijalankan. Min (2004) menjelaskan bahawa berdasarkan kajian yang meneliti kepada agenda media sebagai pemboleh ubah bergantung yang melaporkan berita rasmi kerajaan, pakar, berita berprestij tinggi, rutin wartawan dalam bilik berita, tekanan ekonomi, ideologi dominan dan agenda media juga berfungsi sebagai pemboleh ubah tidak bergantung. Merujuk kepada struktur agenda media dalam kempen yang diketengahkan dalam pilihan raya tertentu seperti yang dilakukan oleh media di Amerika Syarikat lebih cenderung kepada menunjukkan agenda media lebih kepada membentuk agenda kepada masyarakat manakala di Britain pula lebih memainkan peranan sebagai penguat agenda.

Utusan Malaysia merupakan sebuah akhbar arus perdana terawal di Malaysia yang mana telah diasaskan pada 29 Mei 1939 yang memegang kecenderungan pro-kerajaan. Utusan Malaysia adalah akhbar yang diterbitkan oleh Utusan Melayu (M) Berhad. Akhbar Utusan Malaysia diterbitkan pada hari minggu dan dikenali sebagai Mingguan Malaysia. Audit Bureau Circulation (ABC) Malaysia telah mengenal pasti jumlah purata sirkulasi akhbar Utusan Malaysia dari tempoh Januari 2015 hingga Jun 2015 ialah sebanyak 162,639 naskhah setiap hari dan Mingguan Malaysia pula adalah sebanyak 340,953 naskhah (Audit Bureau of Circulations Malaysia, 2015). FMT telah diasaskan sebagai sebuah portal berita harian pada tahun 2009. Portal berita FMT menyediakan paparan berita dan ruang komen 
kepada pembaca atas talian. Hal tersebut adalah bertujuan bagi membentuk sfera awam di kalangan pembaca dan penulis. Portal berita ini dimiliki oleh MToday News Sdn. Bhd. Portal berita FMT merupakan sebuah portal berita bebas yang dikunjungi oleh lebih 20 buah negara, dalam jumlah kira-kira 100,000 orang pelawat dalam portal serta dengan catatan 200,000 pelayar laman portal bagi setiap hari. Penyunting utama portal ini ialah M. Menon dan jawatan penyunting pengurusan pula dipegang oleh Nelson Fernandez. Penyunting berita yang mengendalikan pelaporan berita bagi portal FMT ialah Shahrom Shahrudin. Kajian yang meneliti agenda media dengan keselarian politik ini mengkaji dua jenis media yang berbeza pemilikan bagi menjawab persoalan tentang perbezaan pemilikan media dengan kecenderungan pelaporan berita berdasarkan kepada agenda media masing-masing.

\section{Kaedah kajian}

Kajian ini dijalankan dengan menggunakan kaedah analisis kandungan. Kajian ini yang merujuk kepada data yang diperoleh dari akhbar Utusan Malaysia dan portal berita Free Malaysia Today ini dikumpulkan dengan menggunakan instrumen borang pengekodan. Pengkaji menggunakan dua sampel kajian iaitu Utusan Malaysia dan Free Malaysia Today. Tempoh masa kajian dijalankan adalah bermula daripada tarikh penamaan calon Pilihan Raya Kecil Parlimen Rompin iaitu pada 22 April 2015 hingga tarikh pengundian di Parlimen Permatang Pauh iaitu pada 7 Mei 2015. Pemboleh ubah yang dilihat dalam kajian ini adalah tema berita yang dipecahkan kepada pecahan sub tema tertentu. Pecahan sub tema dibuat sebagai penjelasan yang lebih teliti bagi setiap isu yang diketengahkan sebagai agenda dalam liputan berita yang dibuat oleh media yang berlainan kecenderungan ini. Item berita yang dikaji adalah berita yang melaporkan berita tentang Pilihan Raya Kecil Parlimen Rompin dan Permatang Pauh yang dikumpulkan bagi kedua-dua media bermula dari tarikh 22 April 2015 hingga 7 Mei 2015. Pilihan Raya Kecil Parlimen Rompin dan Permatang Pauh dipilih sebagai skop kajian kerana kedua-dua parlimen ini mempunyai kecenderungan pemilihan parti yang memerintah yang berbeza iaitu Barisan Nasional bagi Rompin dan Parti Keadilan Rakyat bagi Permatang Pauh.

Condong berita yang diteliti dalam kajian pula dilihat dengan pembahagian corak berita yang berbeza iaitu positif kerajaan, positif pembangkang, neutral, negatif kerajaan dan negatif pembangkang. Tema berita yang dikenal pasti dalam liputan berita dikaitkan dengan condong berita bagi meneliti darjah keselarian politik dengan media.

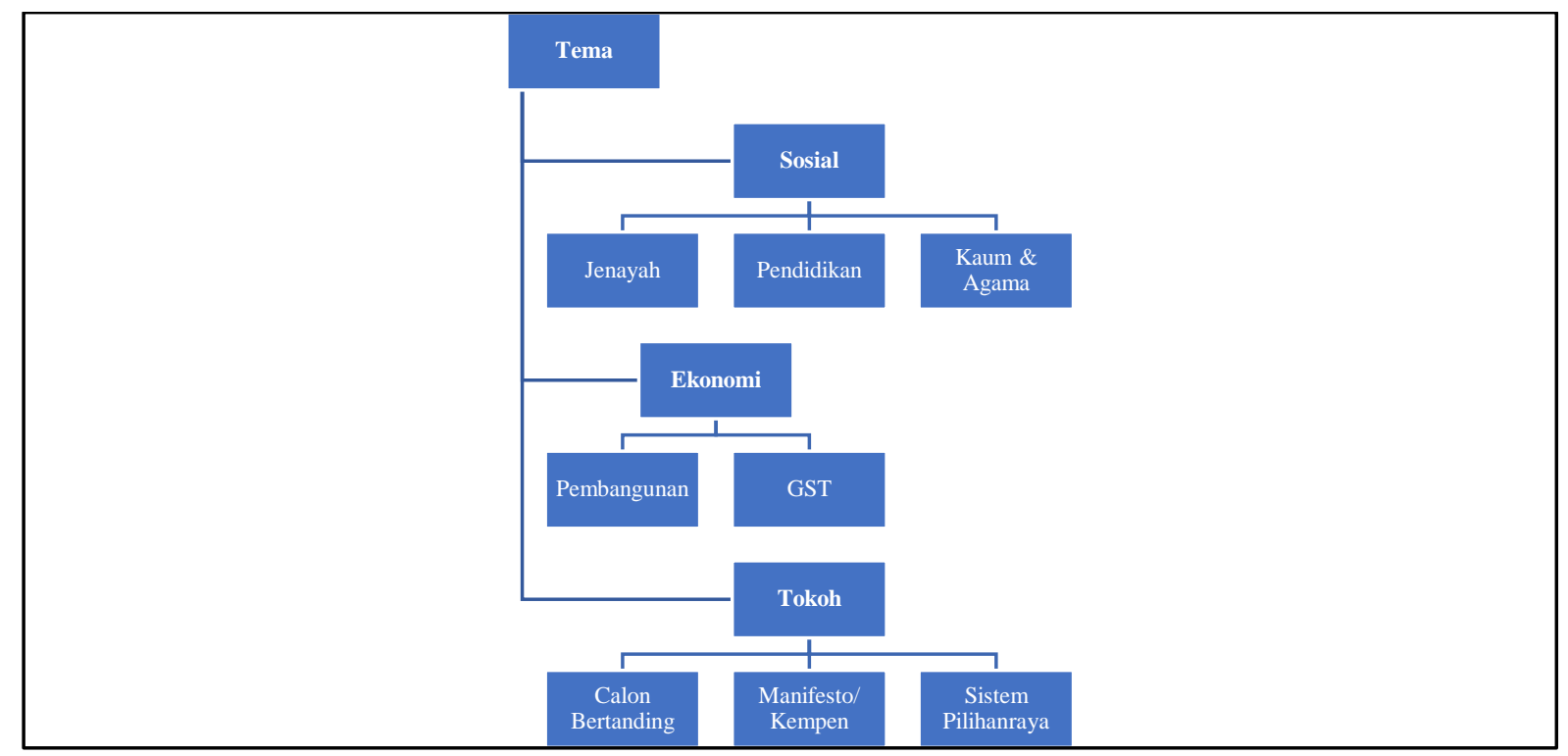


Rajah 1: Tema dan pecahan sub tema yang diteliti dalam kajian

\section{Perbincangan}

Sebanyak 254 buah berita dalam Utusan Malaysia dan 91 buah berita dalam Free Malaysia Today telah dikenal pasti yang melaporkan tentang Pilihan Raya Kecil Parlimen Rompin dan Permatang Pauh 2015. Berita yang telah dikenal pasti ini telah diteliti tema berita yang dilaporkan berdasarkan kepada tema yang dibentuk dan pembahagian sub tema.

Jadual 1: Kekerapan dan Peratus Liputan Berita Berdasarkan Tema

\begin{tabular}{|l|c|c|c|c|c|}
\hline \multirow{2}{*}{} & \multicolumn{2}{c|}{ Tema Berita } & \multicolumn{2}{c|}{ Utusan Malaysia } & \multicolumn{2}{c|}{ Free Malaysia Today } \\
\cline { 3 - 6 } & & Bilangan & \% & Bilangan & \% \\
\hline \multirow{3}{*}{ Sosial } & Jenayah & 4 & 1.6 & 2 & 2.2 \\
\cline { 2 - 6 } & Pendidikan & 1 & 0.4 & 0 & 0 \\
\cline { 2 - 6 } & Kaum \& agama & 14 & 5.5 & 3 & 3.3 \\
\hline \multirow{3}{*}{ Ekonomi } & Pembangunan & 46 & 18.1 & 1 & 1.1 \\
\cline { 2 - 6 } & GST & 5 & 2.0 & 2 & 2.2 \\
\hline \multirow{3}{*}{ Tokoh } & Calon bertanding & 105 & 41.3 & 58 & 63.4 \\
\cline { 2 - 6 } & Manifesto/kempen & 56 & 22.0 & 10 & 11.1 \\
\cline { 2 - 6 } & Sistem pilihanraya & 23 & 9.1 & 15 & 16.7 \\
\hline
\end{tabular}

Sumber: Kajian Lapangan

Jadual 2: Kekerapan dan Peratus Condong Berita dalam Akhbar dan Portal Berita

\begin{tabular}{|c|c|c|c|c|}
\hline \multirow[t]{2}{*}{ Condong Berita } & \multicolumn{2}{|c|}{ Utusan Malaysia } & \multicolumn{2}{|c|}{ Free Malaysia Today } \\
\hline & Bilangan & $\%$ & Bilangan & $\%$ \\
\hline Positif kerajaan & 81 & 31.9 & 30 & 33.0 \\
\hline Positif pembangkang & 2 & 0.8 & 14 & 15.4 \\
\hline Neutral & 68 & 26.8 & 32 & 35.2 \\
\hline Negatif kerajaan & 15 & 5.9 & 5 & 5.4 \\
\hline Negatif pembangkang & 88 & 34.6 & 10 & 11.0 \\
\hline Jumlah & 254 & 100 & 91 & 100 \\
\hline
\end{tabular}

Sumber: Kajian Lapangan

Kajian mendapati bahawa Utusan Malaysia dan Free Malaysia Today memaparkan sub tema calon bertanding sebagai isu utama yang difokuskan dalam liputan berita iaitu dengan catatan 105 buah berita atau 41.3 peratus dan 58 buah berita atau 63.4 peratus. Sub tema paling sedikit yang dilaporkan oleh kedua-dua media yang dikaji adalah sub tema pendidikan iaitu sebanyak sebuah berita atau 0.4 peratus bagi Utusan Malaysia dan Free Malaysia Today pula tidak memaparkan berita dari sub tema tersebut. Berita yang dipaparkan oleh Utusan Malaysia adalah cenderung ke arah negatif pembangkang dengan catatan sebanyak 88 buah berita atau 22.8 peratus manakala berita yang dipaparkan oleh Free Malaysia Today pula mencatatkan kecenderungan yang tinggi ke arah neutral iaitu dengan catatan sebanyak 32 buah berita atau 35.2 peratus. Bagi liputan berita yang mencatatkan jumlah terendah yang dipaparkan oleh Utusan Malaysia adalah berita yang bercondong positif pembangkang iaitu dengan catatan sebanyak dua buah berita atau 0.8 peratus manakala bagi Free Malaysia Today pula adalah berita yang bercondong negatif kerajaan iaitu dengan catatan sebanyak lima buah berita atau 5.4 peratus. Hal ini membuktikan bahawa kedua-dua media memaparkan agenda media yang difokuskan sebagai keutamaan kepada khalayak bagi tempoh masa tersebut. Merujuk kepada dapatan tema yang difokuskan sebagai isu utama dalam liputan berita ini jelas mempamerkan bahawa agenda media yang ditetapkan oleh media, walaupun berlainan pemilikan dan kecenderungan adalah dibentuk oleh faktor keselarian politik. Darjah keselarian media adalah bersamaan dengan darjah keselarian politik. 
Utusan Malaysia lebih memfokuskan kepada liputan berita tentang manifesto tetapi Free Malaysia Today pula menumpukan kepada sistem pilihan raya. Ini membuktikan keselarian politik di mana Utusan Malaysia lebih memfokuskan pada manifesto Barisan Nasional kepada pembaca manakala Free Malaysia Today memfokuskan kepada sistem pilihan raya kerana pembangkang sering kali mempertikaikan ketelusan sistem pilihan raya dan SPR. Dalam erti kata lainnya, isu yang diketengahkan oleh media sebagai isu utama, hal tersebut adalah yang ingin ditonjolkan oleh politik melalui agenda media kepada khalayak. Ujian pekali korelasi yang dijalankan bagi meneliti perkaitan antara keselarian politik media dengan penentuan agenda media melalui tema berita dan condong berita mendapati bahawa tema berita calon bertanding ialah tema berita yang signifikan bagi kedua-dua media yang dikaji iaitu dengan catatan $r=.996$ dan $\mathrm{p}=.004$. Darjah persamaan tinggi dengan nilai korelasi $(r)$ hampir kepada nilai 1 , manakala nilai signifikan $(\mathrm{p}<0.05)$ menguatkan lagi kebolehpercayaan hasil kajian yang dijalankan.

\section{Kesimpulan}

Tema berita yang dilaporkan oleh media berdasarkan kajian, data menunjukkan sub tema calon bertanding sebagai agenda utama yang disampaikan oleh media. Utusan Malaysia dan Free Malaysia Today masing-masing memaparkan tema berita calon bertanding sebagai isu yang paling diketengahkan dalam pelaporan berita iaitu dengan catatan sebanyak 105 buah berita atau 41.3 peratus dan 58 buah berita atau 63.4 peratus. Ini membuktikan bahawa dapatan kajian ini sangat signifikan dalam menjawab darjah persamaan keselarian politik dan media. Agenda media yang ditentukan dalam liputan berita adalah berdasarkan kepada agenda politik dan keselarian di antara kedua-dua (media dan politik) dibentuk melalui pelaporan berita yang dibuat. Selain itu, hasil dapatan kajian ini juga menyokong Teori Penentuan Agenda yang menjelaskan bahawa media memainkan peranan sebagai pembentuk idea dan perkara yang harus difikirkan penting oleh khalayak. Persamaan politik yang selari di antara media dan politik sememangnya perkara asas yang wujud dalam sistem media di negara ini (authoritarian dan liberal). Faktor keselarian politik yang dipegang oleh pemerintah membentuk agenda yang disampaikan oleh media berdasarkan kepada konsep asas yang diterangkan oleh Teori Penentuan Agenda.

\section{Rujukan}

Artero, J. P. (2014). Political Parallelism and Media Coalitions in Western Europe. London.

Audit Bureau of Circulations Malaysia. (2015). ABC Circulation Figures - January to June Monthly Breakdown. Di akses pada 5 Mei 2016, dari http://abcm.org.my/report/latestaudit-reports-january-to-june-2015/

Bahtiar Mohamad, Hassan Abu Bakar, \& Mohamad Khadafi Hj Rofie. (2004). Imej Islam di Media Cetak: Analisis Kandungan Akhbar Mingguan di Malaysia. The Malaysian Journal of Language and Communication, 1(1), 79-98.

Chan, M., \& Lee, F. L. F. (2014). Selective Exposure And Agenda Setting: Exploring The Impact Of Partisan Media Exposure On Agenda Diversity And Political Participation. Asian Journal of Communication, 24(4), 301-314.

Hallin, D. C., \& Paolo, M. (2004). Comparing Media Systems: Three Models of Media and Politics. London: Cambridge University Press.

Kim, S.-H., Han, M., Choi, D.-H., \& Kim, J. N. (2012). Attribute agenda setting, priming and the media's influence on how to think about a controversial issue. The International Communication Gazette, 74(1), 43-59.

Kiong, C. C. (1991). Penentu Agenda: Sumber, Media atau Publik? Jurnal Komunikasi, $7(1), 47-54$. 
McCombs, M. E., \& Shaw, D. L. (1972). The Agenda-Setting Function of Mass Media. The Public Opinion Quarterly, 36(No. 2). Di akses pada 9 Ogos 2016 dari http://www.unc.edu/ fbaum/teaching/PLSC541_Fall06/McCombs and Shaw POQ 1972.pdf

Min, Y. (2004). Campaign Agenda Formation: The News Media in the Korean Congressional Election of 2000. Asian Journal of Communication, 14(2), 192-204. http://doi.org/https://doi.org/10.1080/0129298042000256767

Ramanathan, K. (2003). Asas Sains Politik. Kuala Lumpur: Oxford Fajar.

Shaw, E. F. (1979). Agenda-Setting and Mass Communication Theory. The International Communication Gazette, 25, 96-105.

Swanson, D. L. (1997). The Political Media Complex At 50: Putting The 1996 Presidential Campaign In Context. American Behavioral Scientist, 40(8), 1264-1282.

Syed Arabi Idid. (1994). Penentuan Agenda: Peranan Media Massa dalam Pilihanraya Umum. Kuala Lumpur: Dewan Bahasa dan Pustaka.

Walgrave, S., \& Aeist, P. Van. (2006). The Contingency of the Mass Media's Political Agenda Setting Power: Toward a Preliminary Theory. Journal of Communication, 56(6), 88-109. 